\title{
Religious Conflicts in Multi-Cultural Schools: a Generational Divide between Students and Adults
}

\author{
Mariagrazia Santagati
}

\section{1 \\ Introduction: the Ambivalence of Conflict within the Integration Process of the Immigrants}

For several decades, European countries have been undergoing a transformation towards greater cultural and religious pluralization: in the public debate, religious diversity -deriving from the growing presence of immigrants- has generated concern, misunderstanding, and has been perceived as a threat to the cultural identity of host societies (Foner, Alba, 2008; Wieviorka, 2001).

One of the most consolidated approaches to explain the diffusion of these negative attitudes toward immigrants and their diversities, in the field of social sciences, is the Group Conflict Theory, that predicts that increased ethnic diversities exacerbate in-group/out-group distinction and foster a state of perpetual conflict and competition for limited resources (Blumer, 1958; Blalock, 1967). Hostility toward immigration is considered a defensive and collective reaction to perceived inter-group competition for scarce goods: from the one hand, in a realistic perspective the immigrants are considered competitors in the labor market and in the Welfare system (Zanfrini, 2019). From the other hand, in a symbolic perspective the most violent conflicts arise in the cultural sphere and assume the shape of an identity fear, since the increase of cultural diversity weakens the national identity and could cause a growing clash between civilizations (Huntington, 1996; Bergamaschi, Santagati, 2019).

From a sociological point of view, however, we have to point out that conflict is not necessary negative per se, but is a fundamental element of social life, corresponding to the coexistence of contradictory orientations about motivations, goals, representations, world view, etc. Conflicts include existential, personal, relational, political controversies (Hirschberger et al., 2016), and represent the constitutive dynamics of the individual and collective, material and symbolic dimensions of societies. Undoubtedly, conflict has an ambivalent function, it could be disruptive and violent, but at the same time fruitful and transformative (Simmel, 1968; Dahrendorf, 1959). Within multi-cultural societies, conflict has not a univocal meaning; it does not necessarily coincide with 
violence, but it can play different roles in the relationship between the host society and immigrants, affected by the different political visions and integration models.

Research findings confirm this interpretation of the ambivalence of conflict, remarking that cooperation and conflict are not alternative outcomes of intergroup relations, as they are constitutive and inextricably linked dimensions of the integration process (Pastore, Ponzo, 2012). In this perspective, the literature has also dealt with the role of intergroup contacts in reducing the prejudices towards immigrants. Hostility will be supplanted by positive and supportive attitudes if contacts and relations between the majority and the minority groups develop under specific situational and structural conditions that facilitate mutual respect (Allport, 1954; cf. Zanfrini, 2016). Hereafter, in its evolution, Contact Theory has focused more on interethnic relationships of friendly nature that will reduce prejudices and xenophobic manifestations and will improve empathy toward members of minority groups (Pettigrew, 1997; cf. Valtolina, 2015). More recently, interculturalism, recalling the Contact Theory and its developments, has proved to be the main pragmatic strategy to promote positive and friendly relationships, thanks to the social proximity between natives and immigrants and considering diversity as an individual and public resource (Zapata-Barrero, 2015).

What happens, however, in the educational field? This chapter deals with the appearance, the development, and the management of religious-based conflicts in multi-cultural schools: this is an interesting sub-topic of our research on educational integration in Northern Italy, already presented in Chapters 21 and 22. After a review of the international and Italian research on this topic in the sociological field, we will present some research results concerning the emerging conflicts in Italian multi-cultural schools, in order to describe, analyze, and interpret the role played by religious affiliations. We will do so through a comparison between the points of view of the adults and of the students involved in the focus groups.

From Religious Bullying to Interreligious Friendships in Education: the Contribution of the International Literature

The Palgrave Handbook of Race and Ethnic Inequalities in Education (Stevens, Dworkin, 2014) identifies a key tradition on interethnic relationships including an analysis focused on the religious issues. Within this research tradition, since the Nineties the issue of school violence in multi-cultural schools has received an enormous attention, especially in French studies. According to Debarbieux 
(1998), the growing concern for violence at school coincides with the collapse of the ideology of progress, and with the crisis of both educational institutions and liberal democracies. In this scenario, the process of "ethnicization of school violence" occurs: ethnic minority groups begin to be considered as naturally aggressive, violent, and dangerous for school environments. Other scholars, however, consider school violence as a type of urban violence, since schools with large proportions of children of immigrants are often located in poor areas, where delinquency and violence are part of everyday life (Dubet, 1987). Research emphasizes the impact of social and ethnic segregation as well as the effect of disorganization of these schools on an emerging culture of drift, deviance, and delinquency (Blaya, 2006). These interethnic tensions risk penalizing the school career of students with minority religious background, thus exacerbating a situation of school distress and causing bad performance, educational failures and early school leaving (Bergamaschi, 2013a, 2016).

Recently, in European and North American literature, the new topic of bullying has emerged, although research has focused more on general forms of bullying than on ethnic and religious bullying. This phenomenon refers to bullying that targets another person's ethnic background or another person's cultural or religious identity (Peguero, Williams, 2011). Ethnic bullying (and ethnic/peer victimization) involves a wide range of aggressive behavior, such as verbal (i.e. taunts and slurs) and indirect (i.e. exclusion from a peer group). A definition of religious bullying was introduced by the Beatbullying's Interfaith Project and created by young people participating in the project (2008: 3):1 "being taunted, excluded, or abused physically, emotionally or verbally on the grounds of one's own religious beliefs, affiliation to a given religion, perceived religious identity, or sectarian view by others, including those of other religious groups or belief systems". The survey findings indicate that one in four young people of the UK sample are being bullied, often violently, because of their religious affiliation or because they are perceived by peers as members of a specific faith community. Almost half of the young people involved do not talk about religious or faith issues: they have in fact little support, if they want to talk about their faith. The fact of being bullied, moreover, made many adolescents feel ashamed of their religion, made them question their faith and made them stop talking about their beliefs. Many bullied youngsters could not concentrate in class, would lose confidence and would become scared or angry. Those who have a faith experience denounce verbal abuse, harassment

1 The project was promoted by the UK's leading bullying prevention charity in different waves, reaching in the last editions (2008) a sample of nearly 1,00o students aged 11-16. 
and stereotyping. They are also physically attacked, made feel isolated, and beaten because of their faith.

Other potential tensions are highlighted in the REMC study (Religious Education in Multicultural Europe: Children, Parents and Schools), a European comparative research on the way school and family face religious and moral education of new generations (Smyth et al., 2013). The study shows that some parents are critical toward schools that do not provide religious education for minority faith children, claiming an overemphasis on majority faith culture. Minority faith parents are also more likely to criticize the faith educational approach adopted by schools. A common theme among some minority faith/secular parents is the fear that teachers would isolate or differentiate their children from their peers: some interviewed parents report specific incidents where teachers display lack of sensitivity to minority religious beliefs. Schools tend to avoid the use of explicit religious symbols, but some explicit tensions emerge between Muslim and other faith/belief groups, in relation to the use of religious symbols and to participation in specific festivities.

There has not been, until recent times, an explicit reference to religious diversities in the education research traditions, with exception for school violence and religious bullying. REDCo Religion in Education. A Contribution to Dialogue or a Factor of Conflict in transforming societies of European countries? (Weisse, 2010; Jackson, 2019) can be considered the first comparative research project on religion and education. ${ }^{2}$ The project concerns young people's views about religion, religious diversity and possibilities for dialogue; it involves classroom interactions and conflicts, and it shows teachers' strategies to deal with religious conflict in educational settings. Many surveyed students appreciate the religious heterogeneity in their classrooms, although some prejudices are expressed, too. Students are generally open towards peers with different religious background. However, they tend to socialize with peers from the same background, even when they live in areas characterized by religious pluralism. Moreover, students often express a tolerant attitude more abstractly than practically. The tolerance expressed in classroom discussions is not always replicated in their daily life. Students generally wish to avoid conflict on religious issues, and some of the religiously committed students feel especially vulnerable. Dialogue is the favored strategy for teachers to cope with diversity

2 The project was funded by the European Commission (2006-2009), promoted by the Warwick Religions and Education Research Unit (WRERU). It has carried out a qualitative and quantitative research in eight countries (Germany, England, France, The Netherlands, Norway, Estonia, Russia, and Spain), focusing on religion in the lives and schooling of students aged 14-16. 
in the classroom, but students are more ambivalent about the importance of it since, in practice, not all students are comfortable with the way diversity is managed in schools.

In the studies mentioned above, interreligious relationships in multicultural schools appear two-fold: interreligious dialogue is not always possible in a highly diverse school environment in which different groups of students inevitably have conflicting interests and worldviews. Interethnic and interreligious friendships and conflicts coexist. Conflict does not exclude the mutual recognition of and respect for the other's legitimate presence in a shared social space. Schools are obviously not the only social site for cross-cultural engagement, but they are a perfect illustration of how this respect for others' presence can work in practice (Ho, 2011). In the already quoted Beatbullying's Interfaith Project (2008), many young people interviewed have friends from all religions. Many young people are tolerant and interested in each other's religion. The majority of them have never been bullied because of their faith; their families encourage them to mix with young people from all religions and they feel comfortable discussing about religion with their peers in schools.

\section{Religious Diversity in Italian Educational Studies: an Emerging Tradition}

In Italian studies, a recent research tradition on interethnic relationships can be identified, including studies aiming at analyzing relationships, contacts and conflicts among peers by focusing on immigrant children's relational experiences as an important asset of immigrants' well-being and a crucial dimension of school integration (Azzolini et al., 2019). Within this research line, the focus on religious diversity and school integration is quite underdeveloped and less consolidated in comparison with the other topics.

On the one hand, these studies highlight a condition of relational disadvantage for immigrant students, without clarifying the role of religious background. The loss of social capital due to recent migration may produce distress and tension among peers, and interethnic conflicts (Colombo, Santagati, 2010). These phenomena, however, are ascribed to variables such as social class or gender, but are rarely explained in ethnic, cultural, or religious terms. Pioneering research on this topic affirms that the religious issue is not explicit and is not dealt with in multi-cultural schools (Ottaviano, 2010).

On the other hand, research shows that students with an immigrant background also experience good-quality relationships with classmates and teachers, and they often do not declare relational difficulties within the classroom 
(Besozzi et al., 2009): in general, immigrant students place greater importance on the cognitive dimension of educational integration, whereas they are less concerned with schools as an arena for socialization.

The issue of discrimination and interethnic violence emerges in a couple of studies conducted in schools in Northern Italy (Delli Zotti, 2014). Although peer violence is a common problem, pupils see schools as safe places, since violence mostly happens outside school grounds. The comparison between teachers and students' perceptions of violence reveals the underestimation, on the adults' part, of the ethnic-racial motivations for bullying and other acts of prevarication, as well as the role of gender (males) and (low) social class as catalysts for episodes of school violence. Other studies confirm the diffusion of relational closure towards immigrants among natives, young males, disadvantaged or isolated students, students who have relational difficulties or are unsatisfied with their school environment (Barberis, 2016).

As in French studies, also in Northern Italy tensions among peers are more frequent in classes with a strong multi-culturality and many social problems, where there are low levels of peer exchange and reciprocal support. Specific measures against highly conflictual climates have been created by observing the offensive language used during instances of peer conflict, the development of negative attitudes towards diversity, and the presence of aggressive and violent behavior (Colombo, Santagati, 2014). The same studies also identify "the best school experiences", in which positive classroom climates seem to be characterized by the development of intergroup friendships. In this perspective, the highly multi-cultural institutes can also be interpreted as social contamination labs, multipliers of interethnic social capital, and spaces defining a mixed model of coexistence, in an atmosphere based on openness to diversity (Santagati, 2016).

Schools often offer spaces of (implicit or explicit) exchange in which identities, worldviews, similarities and diversities - also based on religious traits play a crucial role, depending on the institutional, organizational, historicalcultural conditions (Benadusi et al., 2017): the contradictory Italian frame is featured by the lack of awareness among teachers in managing controversies and dilemmas related to different religious traditions (Daher et al., 2017). Moreover, religion and migration represent an ambivalent mix within the educational pathways of immigrant students (and not only for Muslims), and, at the same time, a stigma and a capital independently of the specific religious background (Ricucci, 2017).

A positive experience emerges from a research on the role of students' religiosity in school integration (Santagati et al., 2019): this study shows that religiosity does play an important role as an integration factor, mainly 
because it fosters students' well-being, thus improving their relationships with peers and teachers and promoting their openness to interethnic exchanges. Religiosity appears as a lever to improve tolerance, respect, and intercultural sensitivity. These intercultural competences are experienced through everyday religious practices and lifestyles and are shared by pupils with different origins in schools with a high percentage of immigrants. In addition, religiosity positively affects school integration both for Italian and non-Italian students.

Other analyses reveal that young believers from different faiths appear quite open to religious diversities and are able to interweave interreligious relationships featured by pragmatism, reciprocity and respect between majority and minority groups: this attitude seems to be more difficult for non-Catholic students than it appears to be for Catholic ones, but it is not impossible (Bichi et al., 2018).

\section{The Religious Nature of Conflicts at School: Research Questions}

An overview of the international and Italian studies highlights that religion is still neglected in educational and migration studies, and its role is scarcely considered to analyze the integration process of students with an immigrant background. Especially in Italy, school failure and interethnic conflicts are phenomena that are rarely explained or interpreted by religious factors. However, as pointed out before, religion is often considered a black box of phenomena that are socially and culturally constructed, and it is important to avoid any simplification of the religious issues, considering the effects of the intersection of class, gender, ethnicity, religion, and other factors on educational trajectories (Farris, de Jong, 2014).

The lack of studies invites scholars to examine the role of religion in multicultural schools, especially in producing conflicts or fostering dialogue, affecting relational well-being of students, influencing or preventing violence in the school environment. Our study, based on 14 focus groups involving adults (teachers, school leaders, and parents) and students attending lower secondary schools (as presented before in Chapter 21), try to deepen these issues, in order to describe, analyze and interpret the effect of religious backgrounds on classroom interactions in terms of intergroup tensions and friendships characterizing the school climate.

The research aims at deepening the issue of religious conflict in the classrooms and gathering empirical evidence about the role of religion diversity in educational integration in multi-cultural Italian schools: 
a) exploring the relevance of religion within interethnic relationships in public schools;

b) mapping the religious conflicts within multi-cultural schools, through students' and adults' narratives;

c) facilitating the punctual narration of conflictual events and episodes in order to distinguish motivations, actors, evolving dynamics, and identify words, attitudes, behaviors emerging in conflictual situations, analyzing more in-depth elements which define conflictual and contrasting situation;

d) examining if religion is a triggering factor of interethnic conflicts; observing the religious differences in classrooms and the reactions of adults and students to conflicts;

e) collecting explanations of religious-based conflicts from the different points of view of students and adults.

In the following paragraphs, we are concentrating on the third part of the focus group grid dedicated to religious conflict at school, regarding the discussion on narratives, feelings, and opinions about religious-based disagreements or tensions. The items used in the focus group are three. From the point of view of pupils, the discussion takes in consideration:

a) the reconstruction of a list of religion-based conflict involving themselves or classmates;

b) how they react and cope with conflicts, how they manage such conflicts or how they would like to;

c) the collection of narratives about religion fights, remembering and sharing words, attitudes, gestures.

From the point of view of adults, the focus group includes:

a) the (in)direct observation or the knowledge of religion-based conflicts at school;

b) the way they react and behave facing conflictual situations, what duties they have and what choices they make or would make;

c) the collection of negative school memories and stories of fights for religious affiliations, considering teasing, bullying, and mentioning verbal and physical fights and their evolution.

Finally, the dimensions of the theoretical scheme used in this book (cf. Part 1 and Chapter 21) help us to reconnect the analysis to some key questions:

- How the claim for the expression of the religious minorities' identities become a matter for religious school conflict?

- Are religious frictions and tensions among students with different religious backgrounds connected to different degrees of freedom and autonomy of students from adults' control? 
- Could religion-based conflict and religious discrimination be linked to majority-minority group contrasts, to power disparity, and unequal opportunities in terms of rights of citizenship?

- Are conflictual dynamics compatible with tolerant and civil coexistence in multi-religious school environments? How schools become a common space in which diversities are combined, shared and transformed in the integration process?

These important questions lead us through the presentation of the results of the research, pointing out the differences and the similarities in the narratives of people from different generations with different cultural and religious backgrounds.

Research Results: the Point of View of Students, Teachers, School Leaders, and Parents on Religious-Based Conflicts

In the following paragraphs, we are going to present some results deriving from the content analysis realized by the software Nvivo. We have carried out an initial coding of the discussions deriving from the 14 focus groups ( $\$ 5.1)$, basically by looking for the description of the school conflicts and the main characteristics of these events narrated by students and adults (map/list of mentioned conflicts; actors involved and their role; kind of conflicts, such as among peers, teacher-student conflict, parents-teacher conflict, etc.; space-time coordinates; religious identities emerging during school conflicts).

Then, we will summarize this analysis through a process of focused coding, more precisely by identifying the kind of narratives developed to describe conflicts $(\$ 5.2)$, the variability of conflicts (escalation from verbal to physical harassment, gradation, duration, etc.), the level of importance attributed to religion, the three components of conflicts (words, attitudes, behaviors), the reaction to and the management of conflict.

Finally, we arrive at an interpretative coding, elaborating the idea of religion as one of the core variables (mean or end) of school conflicts, identifying material/realistic and cultural/symbolic explanations (cf. Stephan, Stephan, 2000) that underpins the previous in-depth analysis of religious tensions $(\S 5 \cdot 3) \cdot{ }^{3}$

3 For the different types of coding in qualitative research, cf. Charmaz (2006). 
TABLE 23.1 Number of conflicts mentioned in focus groups by students or adults

\begin{tabular}{lccc}
\hline FG students & No. conflicts mentioned & FG adults & $\begin{array}{c}\text { No. conflicts } \\
\text { mentioned }\end{array}$ \\
\hline B & 10 & 1 BS & 2 \\
2 BS & 3 & 2 BS & 3 \\
3 BS & 3 & 3 BG & 2 \\
4 BG & 3 & 4 M I & 4 \\
5 M I & 3 & 5 M & 1 \\
6 M & 1 & 6 M I & 2 \\
7 M & 0 & 7 M & 1 \\
\hline
\end{tabular}

SOURCE: AUTHOR'S PERSONAL ELABORATION

\subsection{The Description of Conflict}

Thanks to the open coding realized through Nvivo, we can observe that each focus group (hereafter $\mathrm{FG}^{4}$ ) involving students or adults has a $15^{-16 \%}$ coverage of the total discussion regarding school conflicts. The attention dedicated to exploring conflicts is not similar, in terms of time and mentioned examples, among FGs with adults or students. Moreover, there is not a correspondence between FGs conducted in the same schools with adults or students with respect to the importance given to the issue of religious conflicts. For example, the part about conflict is quite developed in FG4-BG-st, and it is particularly important in FG 2-BS-ad, 4-MI-ad, and 5-MI-ad.

Students mentioned a list of 23 examples of conflicts, while adults referred to 15 cases. FG1-BS-st is featured by a very high number of episodes of conflicts, with respect to the other FGs with students and adults: we have to take in consideration that it is the most participated FG (with 14 students) and that it has the highest number of Muslim participants (6 students) among all FGs. We have to remember that $\mathrm{FGs}$ with students are multi-religious and multi-cultural in the participants' composition, while adults' FGs are more homogenous with a majority of Italian, Catholic (and females) participants.

Most conflicts mentioned by students are peer conflicts (19), while few other actors seem to be involved in religious-based tensions in the narratives of students: there are only some cases of a discussion between a Muslim student and a teacher; a friction between a Muslim father and the teacher of his

4 Focus groups have been codified in the following quotes by number (i.e. FG1), school province (i.e. FG1-BS), kind of participants (i.e. FG1-BS-st for students, FG1-BS-1-ad for adults). 
daughter; two cases of religious conflicts are reported from news on television and concern the opposition parents-sons or conflicts among adults. In FG 7-MI-st no conflicts are mentioned.

Almost all the religious conflicts narrated by the students are conflicts that they have witnessed directly (21): in 5 cases, Muslim students reported cases in which they have been victims of religious bullying. Even if these mentioned episodes occurred mainly within school environment and classrooms, in 6 cases students referred to extra-scholastic contexts (oratory, neighborhood streets, television). In 14 cases of the 21 mentioned episodes, students deal with events that take place in the present, while past conflicts are narrated especially by Muslim students, victims of negative religious-based events occurred at school: referring to the past represents a way to make a narrative distance from painful situations.

Students provide a differentiated description of religious identities emerging during school conflicts: although, in most cases, conflicts are developing between Muslim students and the other classmates with no specified religious identity (12 cases), there are individual identities and affiliations that appear, indicating: interreligious conflicts (Muslims-Catholics; a case of Muslim Pakistani versus Indian Sikh) as intra-religious conflicts (among Catholics, Muslims, Protestants), majority-minority conflicts (Catholic students -majority faith group-versus a classmate with a different religious-minority identity); conflicts between atheists and believers; integralist and soft believers (among Catholic, Protestant, Muslim students); practicing and non-practicing students.

Although the religious majority identity of the classroom is not always explicit, there are different cases in which classmates identify a single student representing the religious alterity in the classroom as a victim of teasing and joking: i.e. the case of a Hindu student or a Jehovah's Witnesses student. In some episodes, this hetero-attribution of a religious identity does not correspond to truth and is used only to hurt a weak classmate: a student, son of a Muslim father and a Catholic mother, which is defined Muslim although he is Catholic; a Thai girl teased as Buddhist, even she is Catholic.

The list of conflicts mentioned by adults during the focus groups is more differentiated, if we consider the actors involved: 6 cases consist in peer conflicts involving students; 5 are conflicts between female teachers and Muslim students (only in one case we have a disagreement between a teacher and a Jehovah's Witnesses student); 3 frictions in the school-family relationship concern the fact that teacher perceive Islam as an impediment to gender equality, reporting experiences with Muslim fathers that prevent girls from participating in school activities or impose the veil. It is also mentioned a case of a mediatized contrast among school leaders of the same territorial area about religious symbols and ceremonies (Crib, Christmas party, Crucifix, etc.). 


\section{N. Quotes from students' FG s ${ }^{\mathbf{a}}$}

$1 \quad$ When I arrived in Italy, my Italian classmates did not say anything. After a while they started making fun of me. First, I didn't say anything, but they continued ... One day, there were four, but I was bigger than them: I beat them up. (Male, Senegalese, Muslim, FG 1-BS-st)

2 I don't remember when it happened, I remember that two classmates and friends were involved, a Muslim and a Christian. They wanted to go out, but the Muslim said "No, I have to go to the mosque" and then the quarrel started. "Come on, you don't care about it", said the Christian, and the Muslim reacted. (Female, Italian, Catholic, FG 1-BS-st)

3 One day I went out with my cousin and a friend, they didn't know each other. My cousin wants to become a priest and my friend is an atheist. I don't remember what happened, but my friend cursed, and my cousin got angry. They started fighting, almost slapping each other. (Male, Italian, Catholic, FG 1-BS-st)

4 Two Christian classmates started arguing and fighting: one usually does not go to church, while the other goes. The non-practicing student told the other not to go to church anymore. (Female, Italian, Catholic, FG 1-BS)

$5 \quad$ Last year there was a student who was half Thai and half Italian, she was Christian. Three or four classmates made fun of her, they told her she was Buddhist. (Male, Italian, Catholic, FG 1-BS-st)

6 There was a boy who has a Muslim father and a Spanish mother. One classmate told him "You are a mix" and has continued naming him so. Maybe he teased him because he has parents of different origins, but he is baptized. (Female, Italian, Catholic, FG 1-BS-st)

7 Often my classmate makes signs with his hands ... he also used to swear (Male, Senegalese, Muslim). I saw some of my classmates who made the sign like ISIS, dressed like ISIS, they put here (points at the face) a kind of band and started doing so: TRRR (machine-gun noise). TRRR (laughter). Against the whole class usually, to tease students from different religions. One of my friends is Pakistani, they point towards her. (Female, Moldovan, Orthodox, FG 1-BS-st)

8 That atheist friend of mine, when he sees my cousin or other very Christian people, does this to them (simulates a gesture of prayer). If he sees Muslims, he lies down. He looks at them with contempt. (Male, Italian, Catholic, FG 1-BS-st) 


\section{N. Quotes from students' FGs $\mathbf{s}^{\mathbf{a}}$}

9 In our classroom, there was a boy who teased a girl because she was a Muslim. He continued for a long time, so the teacher made him feel like the girl, she teased him about his Christian faith. He said a swearword and the teacher repeated it, saying "how would you feel if I told you this bad word?" (Male, Italian, Catholic, FG 1-BS-st)

10 Last year there was a Muslim girl in our classroom. She was always silent, a good girl, but everything would happen in the classroom, like stolen things or disappeared, the classmates accused her that it was her religion that told her to do those bad things. She was shy, closed, she didn't know how to defend herself, sometimes she cried. (Male, Italian, Catholic, FG 1-BS-st)

11 In primary school, a girl got angry with me, maybe for something I hadn't even done. She said to the others: "You don't have to talk to her, because if you talk to her, I will not be your friend anymore". I said nothing and I continued staying with the ones who loved me. Slowly they understood that I had done nothing wrong and they forgot everything. (Female, Indian, Hindu, FG 2-BS-st) Some guys are bullies. I wanted to play with them, but they stayed away from me because I was a Muslim. Once, one of them shoved me and I punched him. There were problems, he got hurt: however, he was weaker than me and I couldn't resist. (Male, Senegalese, Muslim, FG2-BS-st)

13 Once I heard in the TV that someone had hurt a person because they were Muslim (Female, Italian, Catholic). Yes ... Moroccans who kill people, just because they are of another religion and not Muslim.

Q: But where happens? Among Moroccans, Is Is ... they say they are Muslims. (Male, Senegalese, Muslim, FG 2-BS-st)

14 In the oratory, a friend spoke in a negative way of my religion and I got angry. Q: And what was he telling you? I won't tell you, bad things. (Male, Senegalese, Muslim, FG3-BS-st)

15 In the classroom, when we talk about religions, there is a Muslim classmate who says that Muslim women must wear a veil by force. The teacher always expresses her disagreement. (Female, Italian, Catholic, FG3-BS-st)

16 In primary school, there was a Muslim boy who beat another who was a Sikh. Someone told me about them, but I knew they used to beat each other frequently, because one was from one religion and the other from another. 
TABLE 23.2 Religious-based conflicts emerging from FGs with students (cont.)

\section{N. Quotes from students' FG s}

Q: Were they of the same nationality? No, one was Pakistani, one Indian. There were always religious hostilities between them. (Female, Italian, Catholic, FG3-BS-st)

17 In my case, we argued about religion. A classmate told me "Moroccan with this veil made of sh...". She teased me because I put the veil and because I am Moroccan. I was in primary school; it was not such a happy past. This classmate and others made fun of me, but I pretended not to hear, and I ignored them, waiting for them to stop. (Female, Moroccan, Muslim, FG4-BG-st)

18 My dad wanted me to put the veil, but my teacher in primary school was against this idea and then there was a quarrel between her and my dad. When I was six years old, I was not able to choose, but after I had understood ... my dad didn't insist. (Female, Moroccan, Muslim) Perhaps the teacher wanted to take her defenses ... about the veil, on the TV news sometimes we heard about girls who don't want to put the veil on and their parents hurt them. (Male, Italian, Catholic) I also agree with him: the choice of religion is a personal choice and it should not be imposed by parents. (Female, Italian, Catholic) But my parents didn't impose me anything. It was my choice, my mom explained to me it was a choice I had to make ... certainly it is not a decision of my parents. (Female, Moroccan, Muslim, FG4-BG-st)

19 I have never seen a dispute between parents and sons about religion, maybe on TV I heard something about this ... On the TV news, you hear about Muslims more than Christians ... I never hear about Christian parents that order their son to go to Mass, and if he does not go, they beat him up. (Male, Italian, Catholic, FG4-BG-st)

20 My friends tease me because I must go to Mass, because it is important for me as it is for my parents. I have to go to Mass; I have to go to catechism class and my friends insult me: "What are you going to do? It is a waste of time". My friends come to the oratory, but mostly for fun and to be troublemakers. (Male, Italian, Catholic, FG 5-MI-st)

21 First, that guy came, and I pushed him away. Later he came back, with their friends. He threatened my friend, telling him not to talk about his religion anymore. When my friend wasn't there, I told him that he didn't have to discriminate other people for their ideas because sometimes the religion we profess comes from our parents. (Male, Romanian, Orthodox, FG 5-MI-st) 


\section{N. Quotes from students' F Gs ${ }^{\mathbf{a}}$}

22 We have discriminated a girl, a Jehovah's Witnesses. I have a classmate: he is a hacker ... he took videos where she sang and put them on YouTube ... and then we removed her from our WhatsApp group. Many of our classroom laughed. When the fact came out, we were in trouble. We discussed it at school even with our teacher and she and we were uncomfortable. (Male, Italian, Catholic) Q: Before, you said that we excluded her because she is the only one of another religion. Right? Yes ... she is Italian. She is not a very nice girl, her behavior is not so good, moreover she belongs to another religion. (Male, Italian, Catholic, FG5-MI-st)

23 There is a classmate who is a bit stupid, he teased and made fun of our Muslim classmate ... I don't know what he said to him. (Female, Italian, Catholic) He made jokes playing with the word Muhammad. (Male, Italian, Atheist) And obviously our Muslim friend got offended ... (Female, Italian, Catholic) We were going back to the classroom and we saw the Muslim classmate holding the other by the neck and dragging him for the whole class. (Male, Italian, Atheist). Because he is an impulsive boy. (Female, Italian, Catholic, FG6-MI-st)

a Each quote from FG is ended referring to the main characteristics of the speaking participant: for students gender, nationality, religious belonging, FG code; for adults, gender, role (Parent, Teacher, School Leader), religious belonging and nationality in the case of foreign parents, FG code. In the FG quotes, sometimes we used the letter Q that stands for Question posed by the FG moderator.

SOURCE: AUTHOR'S PERSONAL ELABORATION

The religious conflicts are narrated mainly by teachers and by some school leaders; only in one case a mother reported an experience lived by her daughter. Adults referred only to recent school conflicts, in which they are not directly involved (except for few cases): they told about fights among students, episodes narrated to them by students, negative experiences of colleagues, disagreement with Muslim parents. In general, they are not the main actors of these conflicts.

Adults do not give, as students do, a differentiated Religious identities emerging during school conflicts: in many cases (10 out of 15), conflicts are developing between Muslim students (or parents) and the other classmates, students, teachers with a not-declared Catholic identity. Often, the division is between 
"we" (probably Catholics, the majority, autochthonous, non-immigrants, etc.) and "they" (mainly Muslims, the minority, foreign-born, immigrants, etc.). Only in few cases do adults refer to other religious identities (Orthodox, Sikh, Jehovah's Witnesses): no reference to intra-religious conflicts between practicing and non-practicing believers, no reference to spread atheism appear (see Garelli, 2016). The adults' view seems a simplified and dichotomist vision of religious diversities at school: majority and minority faith groups, religion of autochthonous and religion of immigrants.

The results of the "Word Frequency Query" carried out by Nvivo have provided a first description of conflicts and have shown that students have a wide vocabulary to discuss conflict: in their FGs, they use words that refer to the form of the conflict (bad words, curses, discussion, insult, etc.) and words concerning feelings and emotions experienced at the beginning and during the controversies (anger, fear, antipathy, etc.). Students also mention some distinctive elements that appear relevant in the context of conflict (i.e. veil, skin color, etc.) and explicit some phenomena that influence negatively the interreligious relationships (prejudice, racism, terrorism and violent radicalism). We can also underline that "freedom" and "woman" are words that are used very often and that turn out to be significant for describing the conflict dynamics from the students' point of view.

As far as adults are concerned, they use words that refer more generally to the form of the conflict (such as problems, difficulties, discussion, etc.); for them, the issues of "woman" (and "veil") and "freedom" are particularly connected to conflict mechanisms; they also introduce a special attention to "integration", while negative attitudes and behaviors are used very few times (i.e. annoyance, mistrust, violence, contempt).

The difference between students' and adults' narratives about conflict can be seen in a relevant gap in the frequency of the use of the words: "freedom" (125 times among students versus 59 among adults) and "woman" (227 among adults versus 33 among students). In the in-depth analysis that will be developed in the following paragraphs, we will see that these are two different interpretative perspectives of the conflict adopted by two different generations:

- The youngest, whose discussions are focused on the issue of freedom to choose one's religion, central in the construction of their own identity, of their educational projects, and of their life plans. In the students' narratives about conflict, the crucial question is the possibility of a free choice of one's religious belonging, independent of the control, the constraints and the imposition of adults;

- The adults' perspective, on the other hand, is mainly focused on the "women" issues, namely gender gap, gender inequality, gender violence (we know that among the adults participating in the FG, as already mentioned, 
TABLE 23.3 Religious-based conflicts emerging from FGs with adults

\section{N. Quotes from adults' FGs}

1 Her classmates started to make fun of my daughter, because they heard of Muslims, of Isis ... a boy said to her "Hey, shut up, you Orthodox!" My daughter replied: "Look, my religion and yours are the same, Christian religions. The boy fell silent. When she came back home, I asked her why the discourse about Orthodox came out. She said that this boy said: "I send Isis to your home" and she answered. (Mother, Moldovan, Orthodox, FG 1-Bs-ad) Once I scolded a boy for his indiscipline. He told me: "You say that words to me because you are Italian and Catholic". I fell silent, but a girl of Moroccan origin rose up. He also said: "I swear by the Koran", she said to him: "First of all, you don't have to swear because right now you don't deserve to approach to the Koran. In this classroom, do not address in that way to the teacher, who has never given proof of treating us as foreigners or of having anything against us because we are foreigners. In this moment she scolds you because you are rude and that's it. (Female, Italian Teacher, FG 1-BS-ad)

3 There was a Muslim boy who always wanted to stay in the classroom during the Religion hour with me. Sometimes I accepted him, but the parents told me they did not want him to be there ... Now he told me that they decided that he could stay, next year. (Female, IRC Teacher, FG 2-BS-ad)

4 It is annoying to hear teachers who say "we and them", talking about their students. It means that there are still barriers, they are not all your students, but there are Italian students and the others. I repeat, there are isolated cases, I am not generalizing, but it happens. In the case I remember, the religious identity of the teachers was very strong, so it was precisely "we Christians and Catholics and they who are not". These are not serious things, but I perceive a mental closure. (Female, Teacher, in charge of intercultural activities, FG2-BS-ad)

$5 \quad$ Last year I had a perfectly integrated Muslim pupil born in Italy, without linguistic problems, with a good family. But he was very problematic in terms of behavior, heavy to bear even for his classmates. One day he said to me: "My classmates don't want to play with me because I'm Muslim!". All his classmates turned towards him and one reacted: "What are you saying? I don't remember if you are a Muslim ... you are a nuisance, for this reason we don't want you!” (Female, Teacher, in charge of intercultural activitsies, FG 2-BS-ad) 
TABLE 23.3 Religious-based conflicts emerging from FGs with adults (cont.)

\section{N. Quotes from adults' FGs}

6 I had two Indian pupils belonging to different castes in the same classroom. They could not talk together. It was very difficult to distinguish the religious factor from the cultural factor, but this was the situation. (Mother/Teacher, Italian, Catholic, FG3-BG-ad)

$7 \quad$ This year I witnessed some quarrels but, in my opinion, these were not religious-based conflicts. Some students told me: "But this girl has offended my God, she has insulted Him". But it was a quarrel born out of other reasons and, after that, the religious factor intervenes. (Female, Italian Teacher, FG3-BG-ad)

8 In this case, we can talk about a generational conflict. For the two Muslim girls who wear the veil, the choice was conditioned by the parents. From my point of view, there was also a conflict between the father and the teaching staff, that pointed out the potential of these girls in the educational field ... Regarding the veil, the two girls accepted it. Instead, the youngest sister, also attending our school and with a strong character, said to a colleague that the veil bothered her. (Female, IRC Teacher) She does not bear it. Every five minutes she goes to the bathroom, I think she wants to take it off. (Female, Italian teacher, FG4-MI-ad)

9 I would give you an example of my experience, when I was a teacher myself. It was not a problem linked to immigration, but to religious differences. I remember a girl who was a Jehovah's Witness, I was explaining the Greek mythology and she wrote me a note asking if I could exonerate her because she was against polytheism. I obviously explained to her the difference between a mythological tale and a religious indoctrination ... Her classmates made fun of her, because they considered it a bit naïve. (Female, School Leader, FG 4-MI-ad)

10 A Catholic boy says: If they are here, we should remove the crucifix from the classrooms; but if we go there, they do not do so. They have freedom here, if we go there, we don't have the same freedom. We must adapt to their life style and therefore they too must adapt ... if we go there, we must follow their rules, while we leave them free not to follow them. (Male, Italian Teachesr, FG4-MI-ad) 


\section{N. Quotes from adults' FGs}

11 Last year there was a controversy because a school principal in this area had decided to boycott the Christmas party. The fact was reported in the newspaper and I remember that a journalist had interviewed me. I think it is not a question of making a crusade for the maintenance of religion, but there are simply symbols of the tradition that have to be respected and preserved. It is sad also to see those who make the crusades to remove all the symbols that distinguish us, as if neutrality was the solution. Instead neutrality per se does not exist ... I am also amazed by those who, facing this wide immigration especially from Muslim lands, want to make a crusade for their own religion. (Female, School Leader) ... In my opinion whoever removes the symbols, does this choice to provoke. We do not make the crib, we do not do the Christmas party, this is a provocation. (Male, Italian Teacher, FG4-MI-ad) We had the case of an Islamic student, who lived her religion as an imposition, she wanted to integrate but could not, because she had an extremist father. He accompanied her to school, she took a step behind him, she could not be equal, she could not do physical education, she could not remove the veil in the classroom, she could not play music, she could not watch movies. The nice thing was that he had found solidarity because she took off her veil in her classroom. She couldn't do homework because she had to study the Koran two or three hours, then she had to do housework. We fought because her father decided to fix the marriage of his daughter. She had to go to her country of origin to get married. She said "I don't want to get married and with a man older than me". We managed in some way, in collaboration with the social services, to conclude lower secondary school with the exam, but unfortunately after she disappeared. (Male, IRC Teacher, FG 5-MI-ad)

An Italian-Brazilian student, who lives alone with his father, abandoned by his mother asks a Maghreb girl of Islamic origin for her vote. There is a certain frustration with respect to school results and, perhaps, mutual competition. The girl does not answer to him, so the boy begins to insult her heavily: "you are a terrorist", "you have it black because you give it to everyone", "you Muslim, have to stay in your country". The girl replies: "you tell me so, you who are son of a Brazilian woman?" (Male, School Leadesr, FG6-MI-ad) 
TABLE 23.3 Religious-based conflicts emerging from FGs with adults (cont.)

\section{N. Quotes from adults' F Gs}

14 In my school there was a conflict between a teacher and a Muslim girl, with mutual recriminations about religious practices, way of dressing, reciprocal intolerance. The teacher declared to be openly intolerant towards other ethnic groups and acted to defend her idea. The behavior of the teacher and the student seemed inappropriate. The student, though insulted, reacted with the same violence. The group class has taken the defense of the girl, seen as a victim and discredited the teacher who was a substitute teacher. (Female, School Leader, FG-6-MI-ad)

15 An Italian student has targeted a Muslim classmate, until the point of tear off her veil with contempt. (Female, Italian Teacher, FG-7-MI-ad)

SOURCE: AUTHOR'S PERSONAL ELABORATION

women are overrepresented). Religion, by the adults' groups, is represented, in the gender conflict, as an instrument of domination by men over women and as a justification of women's submission to men's power and control.

\subsection{The Analysis of Different Kind of School Conflicts}

From the point of view of adults, religious-based conflicts are collocated in continuum, from "light conflicts" (verbal conflicts, as joking, teasing), often corresponding to problematic attitudes (intolerance, contempt, etc.), to even more "serious conflicts" (bullying, physical violence, etc.). Considering the different kinds of conflict, peer conflicts through adults' words are an escalation of teasing, provoking, offending, silencing, not bearing, insulting, getting angry, exasperating. The violence is mainly a verbal violence and harassment, expressed through shouted words, strong and intolerant language. Among the narrated episodes, only one includes a violent behavior (tearing off the veil of a Muslim classmate, cf. Table 23.3 n. 15).

Between students and teachers, we can observe some disagreements concerning the influence of religious belief on the lifestyle and study choices of Muslim girls (as we have previously commented in the analysis of word frequency query results $(\$ 5 \cdot 2)$. (Female) teachers report stories of reciprocal accusation, insinuation, rudeness, delegitimization, and lack of respect by students and parents of different religious background (mainly Muslim) towards them. In one case, there is a distinction between "we Catholics" - teachers 
TABLE 23.4 Word frequency query concerning conflict and problems in relationships

\begin{tabular}{lrlr}
\hline Word - FG students & Word count & Word - FG adults & Count \\
\hline Conflict & $\mathbf{1 4 9}$ & Woman & $\mathbf{2 2 7}$ \\
Freedom & 125 & Conflict & $\mathbf{1 5 6}$ \\
Word, Swearword, Curse & 59 & Problems & $\mathbf{1 2 2}$ \\
Veil & 46 & Difficulties & 79 \\
Problems & 39 & Veil & 67 \\
Anger & 39 & Freedom & 59 \\
Woman & 33 & Integration & 48 \\
Discussion & 27 & Discussion & 39 \\
Color & 23 & Words & 35 \\
Prejudice & 23 & Color & 9 \\
Racism & 23 & Annoyance & 9 \\
Isis / Terrorism & 22 & Mistrust & 8 \\
Antipathy & 20 & Violence & 8 \\
Fear & 18 & Insult & 7 \\
Insult & 15 & Contempt & 6 \\
& & &
\end{tabular}

SOURCE: AUTHOR'S PERSONAL ELABORATION

with closed religious identities -and "them"- students of other religions. In school-family conflicts, dilemmas on religious symbols appear (whether to hang crucifixes or not; whether to put up Nativity scenes at Christmas or not; whether to celebrate Christmas with a party or not, etc.). In these cases, the discussions often concern religion as an imposition by Muslim fathers to daughters, with negative implications for school and life choices: female teachers remark their negative opinion and aversion toward these behaviors. At stake there are different world views, different ideas about the role of women in school and society, sometimes a different treatment at school of students with a different migrant or religious background (Dronkers, Kornder, 2015).

From the analysis of the three main components of religious-based conflicts narrated by adults (Table 23.5), we can point out that there is a correspondence between words and attitudes emerging in conflictual situation (Santagati, 2014: 197). Conflicts appear mainly as verbal quarrel or dispute (see conflict 
TABLE 23.5 Words, attitudes, behaviors emerging in religious-based conflicts from FGs with adults

\begin{tabular}{|c|c|c|c|}
\hline N. Conflict & Words & Attitudes & Behaviors \\
\hline 1 & Teasing, insults, quarrel & $\begin{array}{l}\text { Simplification, } \\
\text { stereotyping }\end{array}$ & $\begin{array}{l}\text { Go home (look for } \\
\text { parent support) }\end{array}$ \\
\hline 9 & $\begin{array}{l}\text { Teasing, } \\
\text { misunderstanding }\end{array}$ & $\begin{array}{l}\text { Prejudice, } \\
\text { misinterpretation }\end{array}$ & Dedicated lesson \\
\hline 11 & $\begin{array}{l}\text { Discussion, quarrel, } \\
\text { dispute }\end{array}$ & Provocation & Boycott Christmas party \\
\hline 7 & Quarrel, curse & Aggressiveness & Look for teacher support \\
\hline 4 & $\begin{array}{l}\text { Distinction "we and } \\
\text { them" }\end{array}$ & $\begin{array}{l}\text { Closure toward } \\
\text { religious diversity }\end{array}$ & Physical distance \\
\hline 2 & $\begin{array}{l}\text { Scolding, complaint, } \\
\text { blame }\end{array}$ & Playing the victim & $\begin{array}{l}\text { Discriminatory } \\
\text { treatment }\end{array}$ \\
\hline 5 & Complaint, quarrel & Playing the victim & $\begin{array}{l}\text { Unbearable, problematic } \\
\text { behavior }\end{array}$ \\
\hline 8 & $\begin{array}{l}\text { Complaint, } \\
\text { disagreement }\end{array}$ & Resistance, patience & Wear or not the veil \\
\hline 10 & Complaint, dispute & $\begin{array}{l}\text { Provocation, lack of } \\
\text { reciprocity }\end{array}$ & Repeated discussion \\
\hline 3 & Refusal & Closure of parents & Attend or not IRC \\
\hline 12 & Refusal & Extremism, control & $\begin{array}{l}\text { Support to conclude Sec } \\
\text { School }\end{array}$ \\
\hline 6 & Not talking together & $\begin{array}{l}\text { Prohibition, } \\
\text { traditionalism }\end{array}$ & Remain astonished \\
\hline 13 & $\begin{array}{l}\text { Verbal violence, sexist } \\
\text { language }\end{array}$ & $\begin{array}{l}\text { Frustration, } \\
\text { competition }\end{array}$ & Educational failure \\
\hline 14 & Recrimination, dispute & Intolerance & $\begin{array}{l}\text { Students against } \\
\text { substitute teacher }\end{array}$ \\
\hline 15 & Verbal violence & $\begin{array}{l}\text { Arrogance, } \\
\text { prevarication }\end{array}$ & Tear off her veil \\
\hline
\end{tabular}

SOURCE: AUTHOR'S PERSONAL ELABORATION

nn. 1, 4, 7, 9, 11), including teasing, naming, insults (and sometimes curses), controversies, linked to specific ways and attitudes towards religious diversity. In these quarrels, adults discuss: 
- Dynamics of simplification and stereotype use concerning religious belonging and identity;

- Provocations triggered by the (ab)use or the refusal of religious symbols and signs;

- Misunderstandings/misinterpretation, confusion between cultural contents of subjects of study and religious indoctrination;

- Presence of close-minded adults that behave differently towards people and pupils depending on other religious background;

- Mental, discursive and physical barriers created to foster insiders-outsiders distinction also in the educational field, as in the access to relevant social knowledge (Merton, 1972).

The analysis of "words" expressing conflict in the narrative of adults, reveal various cases of complaint, disagreement, recrimination and disputes (conflicts no. 2, 5, 8, 10, 14), especially in wide dynamics involving students, classmates, teachers (and sometimes other adults). Some students, in these situations, decide to "play the victim" in order to look for justifications and legitimization of their bad behavior, accusing classmates and teachers of discriminating and treating them unjustly and unequally because of their different religious background. Other verbal disputes refer both to attitudes of resistance to family control and religious impositions on daughters, and of acceptance of conditioned choices concerning school, life, social participation of women; and to challenging attitudes of provocation concerning reciprocity, reciprocal adaptation, religious freedom in Italy and in the countries of origin of students with an immigrant background.

In the last group of conflicts mentioned by adults (no. 3, 6, 12-15), we have listened to and read the description of episodes of verbal violence including offenses, recrimination, verbal attacks, sexist language, ethnic and religious prohibitions and refusals. Insults often intersect and mix multiple offenses concerning religion, color, nationality, gender, etc. (recalling the interpretative intersectionality approach: Anthias, 2013). These are cases in which words are used as "guns" to hurt someone for his/her intolerable religious diversity. This violent language could be interpreted as a consequence of mental closure, violent extremism and radicalism linked to a traditionalist and conservative vision (Santagati et al., 2017), which justifies unequal treatment of diversities, intolerance, frustration and competition among disadvantaged and lowperformer students, arrogance and prevarication corresponding to forms of religious bullying (Beatbullying, 2008).

Adults briefly refer to the (real, imagined, wanted) reactions to face conflictual situations. Although they desire to demonstrate that school conflicts are under their control, in different cases teachers stay in silence, watching the reactions of peers in order to stop the conflicts in the classroom. In most cases, 
teachers intervene by starting open discussions during their lessons, by trying to facilitate dialogue among classmates, by proposing an exchange of views about religious diversity, clarifications in controversies and disputes, and by looking for cooperation with other educational agencies to prevent early school leaving of students discriminated or conditioned from their religious belonging (Bergamaschi, 2016).

In their aspirations, adults think it could be important to intervene to promote and defend respect for everything (people, culture, religion, etc. FG 2-BS-ad), since the parents perceive this respect, and consequently can trust schools and teachers more. However, religion is not always considered crucial by teachers in the FGs: the idea they have of conflict prevention is to educate students from all the points of view, including the religious dimension (Cuciniello, 2017), stimulating the expression of specific religious identities, especially during their construction and definition (FG3-BG-ad), working on tolerance, openness to diversity, non-violent communication and emotional intelligence (FG 7-MI-adults). The ideal for teachers is to face conflict with adequate authority and punishment (bad conduct notes on their permanent record, suspension in more serious cases, etc.), restore order, listen to everyone's reasons, teach lessons on the conflictual matter (Sclavi, Giornelli, 2014): teachers will be conflict mediators working at school (Santagati, 2004) and this will give the two sides of the conflict the opportunity to listen to each other and listen to the reasons that led to a certain behavior, in order not to repeat it (FG-7-MI-ad).

From the students' point of view, the different type of conflicts depends on the insult gradation - "if they insult me a little, I don't react, but if they insult me a lot, I get angry" (Male, Pakistani, Muslim, FG-1-BS-st) or/and on the time duration - "if someone is teasing me, at the beginning I'm not angry, but if he continues for a long time I get angry" (Male, Senegal, Muslim, FG-1-BS-st). Students are very good at describing the escalation of conflicts, giving detailed tales of words, attitudes, behaviors emerging in conflictual situations.

Analyzing the three main components of religious-based conflicts narrated by students (Table 23.6), we can find several pronounced (and not pronounced) words that mark and characterize the conflictual climate among peers or the student-teacher interaction. Most conflicts are based on teasing a student with a different religious background (no. 1-5-6-8-9-22): teasing becomes more irritating when it includes verbal insults, attribution of false names and religious identities, laughs. The "perpetrators" do not seem to know that they are dealing with a delicate subject that can hurt the classmate designated as the "victim" very much. In fact, these verbal strategies refer to superficiality, antipathy, but also to contempt and harassing attitudes: practicing students or students from a minority faith group are victims of derision of their religious practice. Their 
TABLE 23.6 Words, attitudes, behaviors emerging in religious-based conflicts from FGs with students

\begin{tabular}{|c|c|c|c|}
\hline N. Conflict & Words & Attitudes & Behaviors \\
\hline 1 & Teasing & $\begin{array}{l}\text { Superficiality, } \\
\text { derision }\end{array}$ & $\begin{array}{l}\text { (Criticized) religious } \\
\text { practice, fight }\end{array}$ \\
\hline 5 & Teasing, false naming & Superficiality & $\begin{array}{l}\text { Emphasis on } \\
\text { diversity aspects }\end{array}$ \\
\hline 6 & $\begin{array}{l}\text { Continuous teasing, false } \\
\text { naming }\end{array}$ & Superficiality & $\begin{array}{l}\text { Emphasis on } \\
\text { diversity aspects }\end{array}$ \\
\hline 8 & Teasing, offense & Contempt & $\begin{array}{l}\text { Simulation of gesture } \\
\text { of prayer }\end{array}$ \\
\hline 22 & Teasing, laughs, discussion & Harassing attitude & $\begin{array}{l}\text { Exclusion, } \\
\text { cyberbullying }\end{array}$ \\
\hline 9 & $\begin{array}{l}\text { Continuous teasing, bad } \\
\text { words }\end{array}$ & $\begin{array}{l}\text { Disrespectful } \\
\text { attitude, no empathy }\end{array}$ & Scold of the teacher \\
\hline 3 & Curse, offense & $\begin{array}{l}\text { Provocation, } \\
\text { aggressiveness }\end{array}$ & Fight, slaps \\
\hline 7 & Swearwords & $\begin{array}{l}\text { Provocation, } \\
\text { harassing attitude }\end{array}$ & $\begin{array}{l}\text { Simulation of } \\
\text { terroristic action }\end{array}$ \\
\hline 10 & Blame, false accusations & Provocation & $\begin{array}{l}\text { Cry, inability to } \\
\text { defend herself }\end{array}$ \\
\hline 17 & Quarrel, swearwords & Provocation & $\begin{array}{l}\text { Negative reaction to } \\
\text { veiled girl }\end{array}$ \\
\hline 23 & Quarrel, curse, offense & Group-centrism & Fight \\
\hline 20 & Quarrel, insults & Group-centrism & $\begin{array}{l}\text { (Criticized) religious } \\
\text { practice }\end{array}$ \\
\hline 4 & Quarrel & Group-centrism & $\begin{array}{l}\text { (Criticized) religious } \\
\text { practice, fight }\end{array}$ \\
\hline 2 & Quarrel, dispute & Group-centrism & Aggressive reaction \\
\hline 15 & Quarrel, dispute & Control, resistance & Wear or not the veil \\
\hline 18 & Quarrel, dispute & Control, resistance & $\begin{array}{l}\text { Restriction of women } \\
\text { autonomy }\end{array}$ \\
\hline 11 & $\begin{array}{l}\text { Threat, refusal of } \\
\text { interaction }\end{array}$ & $\begin{array}{l}\text { Aggressiveness, sense } \\
\text { of injustice }\end{array}$ & $\begin{array}{l}\text { Exclusion from the } \\
\text { classroom }\end{array}$ \\
\hline 21 & $\begin{array}{l}\text { Threat, refused } \\
\text { communication }\end{array}$ & $\begin{array}{l}\text { Arrogance, sense of } \\
\text { injustice }\end{array}$ & Move and get away \\
\hline
\end{tabular}


TABLE 23.6 Words, attitudes, behaviors emerging in religious-based conflicts from FGs with students (cont.)

\begin{tabular}{llll}
\hline N. Conflict & Words & Attitudes & Behaviors \\
\hline 13 & $\begin{array}{l}\text { TV news: religious-based } \\
\text { murders }\end{array}$ & $\begin{array}{l}\text { Prejudice, } \\
\text { stereotyping }\end{array}$ & $\begin{array}{l}\text { Religious-based } \\
\text { violence }\end{array}$ \\
& TV news: parent-children & Control, resistance & (Possible) religious- \\
19 & dispute & based violence & Physical distance, \\
& Unrepeatable words & Arrogance, & prevarication \\
12 & Anrepeatable words & Arrogance & Aggressive reaction \\
14 & No words & Hostility & Fight \\
\hline
\end{tabular}

SOURCE: AUTHOR'S PERSONAL ELABORATION

religious diversity is stressed, diminished and criticized; phenomena of religious bullying (also in the version of cyberbullying occurring over digital devices like cell phones, computers, and tablets, in social media or in chats, etc.) take place (cf. Agirdag et al., 2011; Llorent et al., 2016). The exclusion of some students from the classroom because they are excessively different from the other classmates, as well as physical contrasts and fights, also happen as complements to quarrels, arguments, and negative attitudes. In this conflict, unfortunately, "some teachers do not even try to listen, and some others pretend to understand, even if they haven't understood and end up punishing who is in the right" (Female, Italian, Catholic, FG1-BS-st).

Sometimes, in conflicts described by students, teasing is associated to swearwords, curses and blasphemies, verbal offenses, insults, bad words, false accusations (no. 3-7-10-17-20): dynamics of provocation, aggressive and harassing attitudes, absence of empathy towards the teased victims, as well as provocative inclinations aimed at sparking conflicts appear. These negative orientations, on the one hand, often turn into fights, physical violence, worrying simulations of weapons' use (and terroristic attacks), as well as disrespect and disobedience to the teacher's authority. On the other hand, they also create the feeling of being defenseless, sad, isolated and lonely in the classroom.

Quarrels and disputes narrated by students (conflicts no. 2-4-15-18-20-23) introduce the interesting topic of group-centrism (Kent, Burnight, 1951), that is the idea that one's own culture is better than any other culture. This inclination, emerging from students' FGs, consists of evaluating other religious beliefs, practices, and affiliations from of one's own personal perspective, on which is 
based both the belief in the superiority of one's own group and the contempt for outsiders.

We call this attitude group-centrism, since it is exercised not only on an ethnic, religious, cultural (etc.) basis, but also by some groups towards other groups (Catholics versus Muslims; Atheists versus Catholics or Muslims; practicing versus not-practicing believers; etc.). Group-centrism is a crucial attitude to interpret continuous controversies in which at stake there is the inclusion of "one student" in the majority group of classmates (who are seen as similar, united, and strong). Such inclusion can be attained by avoiding causing the student to feel isolated, weak, or different because of his/her religious, ethnic and cultural belonging, identified as "strange" because of his/her behavior or their way of dressing.

By observing from the point of view of the younger generation, among the various disputes we can see some discussions about the controversial issue of autonomy and control on girls and women exercised by fathers and men through religious traditions and practices. This discourse adds further elements about how adolescents perceive themselves as a group (experimenting youth-centrism) in front of the group of adults (Maassen et al., 1992). Students agree on the fact that the religious choice should be made freely and underline the importance of accepting and recognizing other religions. Accordingly, they are against adults who want to impose (sometimes in violent ways) choices concerning religion and highlight the need of being independent of adults and parents and of resisting to their impositions, with consequences on the physical and mental restriction of women's autonomy.

In conflicts no. 11 and 21, we can find verbal threats and accusations deriving from aggressive, provocative and arrogant attitudes. These episodes are characterized by an explicit refusal of the interaction with the "others" by members of the majority group, driven by the adoption of self-centered attitudes during the construction of a social act, which leads to conflict (in the constructionist view of Mead (Athens, 2012)). These classmates, sometimes, also refuse to communicate with a "super-diverse" victim, often fragile, and seen as not able to defend him/herself, or even not able to participate in the classroom relational dynamics because of his/her religious belonging. Among these last students, we can observe an increase in their perception of being treated unjustly by their classmates, of being discriminated for their religious ideas (without having done anything wrong). Sometimes they are beaten from the majority group, they suffer physical violence and harassment (almost absent in the stories of conflicts as told by adults), other times they experiment the exclusion from the classroom, with the indifference or the cruelty of the whole group. 
In the last group of conflicts (no. 12-13-14-16-19), finally, the violence of religious-based conflicts increases even more in the narratives of students. In fact, because of the seriousness of those conflicts, they discuss the news broadcast on television (religious-based murders, parent-children violent disputes about religion choices) and they consider the verbal dynamics of conflict in which they are involved as controversies made of "unrepeatable bad words", hostile words, offenses to God or to the prophets (cf. Lipperini, 2018, about the project "Parole ostili" (hostile words)). We would like to point out that, in this kind of conflicts, a sort of religious-based violence is described. A violence motivated by or in reaction to religious belonging, practice or belief, a violence involving adults and young people caused by some religious aspects, a violence triggered by some religious features of the victims or of the attackers (Hall, 2013).

What are the reactions and the strategies used by students to face a conflictual situation? As in some other studies (Van Praag et al., 2016), students tend to withdraw from classroom discussions and conflicts about religion where they feel that their values are different from those commonly expressed. As these young people from minority groups do not appear to receive a great support from peers or adults, they tend develop their own strategies of coping and survival, through silence, indifference and immobility, trying to hide their religious identity to stop the conflict, through passive waiting. In several cases, students show different emotional reactions: anger, sadness, annoyance, fear, irritability, displeasure, violence. Rarely do they talk about the mediation or the intervention of peers or teachers. In general, students think that sometimes it is necessary to involve teachers in the conflict management, while parents have to stay out of the conflict not to complicate the situation. Teachers have to talk to students trying to mediate and to explain the importance of the respect of others and the injustice of religious offense. Then, sometimes, to punish physical violence, they have to use the appropriate measures, such as school suspension, and most of all they have to give comfort to the victim.

Teachers have to intervene without scolding those who made the insult and by giving comfort to the victim ... Maybe the student feels under pressure and does not want to profess his religion any longer ... Maybe the teacher's intervention can lead him fight the anxiety he has inside. (Male, Italian, Catholic, FG1-BS-st)

\section{5•3 Realistic or Symbolic? The Conflict Interpreted by the Focus Group Participants}

The last part of our analysis of school conflicts concerns the explanation and the interpretation that $\mathrm{FG}$ participants directly attribute to the role of religion 
in conflicts, and it takes in consideration different interpretative perspectives emerging from each $\mathrm{FG}$.

For students, religious-based conflicts and disagreements are an important and personal matter, since it is linked to the construction and the definition of their cultural identity, in relation to their familiar history and to the migration experience. In this perspective, religion represents an important cultural dimension perse, since it deeply affects the development of the students' identity.

The importance of one's religion belonging appears from the fact that religious issues are used during conflicts to hurt students with a different religious background. In FG1-BS-st, we can clearly observe a vision of religion as a way of life or lifestyle (Berzano, 2011), a way to identify oneself. For this reason, religiousbased threats and violence deeply hurt the personal identity: these offenses hit students in their most fragile and intimate dimension, targeting a (super)diversity sometimes considered as socially inassimilable or unacceptable. Religious belonging seems to represent, for students, the weakest point in their inclusion pathways: curses or insults, and other negative attack strategies on religious topics, mark a real distance and create a dramatic rupture in peer relationships. Religion is considered as a weapon that increases the chance of harassment and of suffering for vulnerable victims, implying the feeling of a perceived exclusion, especially when an attitude of contempt towards the other's religion emerges.

My classmate makes fun of her because she belongs to a different religion. (Female, Moldovan, Orthodox)

He was pointing at me, saying to the teacher that it was my fault, surely because I belong to another religion, they hit more those who are not Italian and who are not Catholics. (Female, Moldovan, Orthodox)

I think the people who tease about religion don't really want to make fun of religion, they don't care. Religion is seen as a weapon to tease you even more with contempt. (Male, Italian, Catholic, FG 1-BS-st).

The description of the conflict dynamics provided by the adolescents, in fact, reflects the functioning mechanism of an apparently homogeneous group (in terms of religion, culture, language, clothing style, skin color, etc.: cf. FG-6-MI-st) that exercises its cruelty against a single student because of his/ her difference in religious terms. The majority group attacks students who appear distant and different from the group, expressing either indifference or ability to deny, exclude and reject this religious diversity. Classmates end up turning into "a pack of wolves that attack a vulnerable pray": this opposition between a group of students apparently similar in the religious background 
and one single student with a clear religious (Muslim) identity, gives evidence of the imbalance in relations crossing a multi-religious classroom, in which power disparity and majority supremacy is expressed and confirmed, identifying a target excluded by the group.

Q: But what is the origin of this quarrel?

This quarrel was born from the stupidity of people. (Female, Italian, Catholic)

No, I think the cause of the quarrel was the religion, because they were friends. Given that religion is a way of identifying oneself, being teased about that topic can be annoying and I know well me too. I am an atheist and, in the classroom, they make all the stupid jokes and I can say that it is very irritating. I have never reacted to these things because I am not an impulsive boy. I must say, however, that there is a lot of aggregation of my classmates to the group of those who made fun of. They are like wolves that run in a pack, if you come off the pack then you are the target too. (Male, Italian, Atheist, FG6-MI-st)

Religion in some cases (FG-2-BS-st) is considered the primary cause of difference, difficulty (and deficit) of immigrant students, therefore provoking conflicts and religious bullying, given the spread of negative prejudice according to which immigrant pupils of other religions (especially Muslims) are naturally incapable and sometimes also intolerant, violent, extremist and terrorist.

Q: What were these arguments about?

They depend on my religion, sometimes on my color ... teachers divided us into groups to do something and if I wasn't able to do that, they would start telling me "she's not able to because she's Indian".

Q: But to what did they refer?

More to religion than nationality. Before, I couldn't really understand, now I understand. (Female, Indian, Hindu, FG2-BS-st)

Sometimes (i.e. FG-4-BG-st), religious and immigrant backgrounds are confused and mixed, thus representing together the usual issues used to create division and peer conflicts. The positive rhetoric of classrooms as united and cohesive groups, in which religious differences are not taken into account, seems to apply mainly to the majority faith group (of Catholics), while the students belonging to minority groups are discriminated do not have many friends. 
The quarrel started not because of religion, I do not talk about religion, I do not tease, I do not insult the religion of one of my classmates. It happened to me more because of the nationality issue. (Male, Italian, Catholic)

In my opinion, as he said, there is no quarrel over religion or nationality, but afterwards there are people who always bring up those topics together and use religion, origin, nationality. (Male, Italian, Catholic, FG 4-BG-st)

The discussion developed in the same FG-4-BG-st, however, points out the seriousness of religious-based conflicts, as they concern family identity, including religious, social, ethnic, cultural belonging. Religion, in fact, appears as a crucial and substantial element linked to familiar and collective identity. Religious conflicts are, for students, mainly identity conflicts, based on an identity divide involving the position of families towards religion. As we have previously discussed $(\$ 5.2)$, religious belonging is important because it concerns a central question in the growth of new generations: autonomy/independence from parents through a free acceptance or a refusal of religious identity of the family, on the one hand; religious impositions and control from parents in religious beliefs or practices, on the other. Indeed, the dichotomies continuitydiscontinuity, tradition-innovation, conservation-change are constitutive of the social dynamics of socialization and education of new generations, of intergenerational relationships, of cultural and religious transmission, dilemmas which continue to accompany the evolution of social life (Arendt, 1972).

Her parents made the right choice because it is her decision, in my opinion the religion must not be imposed. (Male, Italian, Catholic)

As far as religion is concern, they must not force you because if you do not wear the veil, you do not do anything wrong. (Female, Kosovar Muslim)

I also agree, the choice of religion is one's own choice and it should not be imposed by parents. (Female, Italian, Catholic, FG4-BG-st)

The link between religion and family is clarified even more in FG5-MI-st: students reiterate that discriminating for religious ideas is considered to be particularly unfair by new generations, because it is seen as a choice made by parents, just like the choice to immigrate. In general, we can state that students 
want to represent themselves as active and free in the transmission process of religious belief.

Do not discriminate other people for their religious ideas, because sometimes the religion we profess comes from our parents. For example, I am an Orthodox, but I would like to become a Catholic as soon as possible. I like being Orthodox, but I like more Catholic ideas ... do not discriminate against people for their ideas and their religion because many times it is not because they choose this religious, but their parents did. (Male, Romanian, Orthodox, FG5-MI-students)

As seen before, adults tend to minimize school conflicts, which are latent, not very dangerous, temporary and not problematic: they affirm that the religious issue does not seem to be very important and relevant at school; conflicts are mainly a personal, intimate, relational, extra scholastic or eventually ethnic matter that is connected to the adolescent dynamics of like-dislike or inclusion-exclusion from a friends' group. From the point of view of adults, unimportant conflicts happen because it is all under adults' control.

For adults, moreover, religion is mainly a pretext and a justification for conflicts. Conflicts that are more dangerous are especially linked to immigration, to a negative view of the immigrant and the problem they bring, to a nonacceptance of migrant people, and to the fear of the Otherness. Diversity is perceived as more static, strong, divisive and excluding, where it is based on religious dogma (FG4-MI-adults).

In my opinion, there are conflicts linked to non-acceptance of the immigrant. So, in this frame, there have been and there are conflicts. Not in the sense of non-acceptance because you are Muslim. Because if you are a Muslim, I accept you, but if you are an immigrant, I begin to make a distinction. The strong conflict is that of immigration because of what students hear in their families. The climate is totally contrary to immigration and therefore these guys, here, have these attitudes of difficulty ... the immigrants come here to Italy and take something away from us. This is a conflictual perspective, but I'll say more. Because of a personal experience, I had fights with colleagues since their idea was: “Couldn't they stay at home instead of coming here to create a lot of problems?". (Male, Italian Literature Teacher, Italian, Catholic)

Q: But ... what about the religious factor?

In general, I believe the problem is the fear of difference and diversity is probably perceived as more static where it has a religious dogma behind it. Perhaps it is this. (Female, Italian, School leader, Catholic) 
Going back to the religious discourse, it depends on how much a boy feels or doesn't feel to be religious, and, consequently, he defends his idea based on this feeling ... I have not seen among boys any conflicts for religious reasons because I think that religion is a bit personal, there could be a discussion linked to the need of knowing the religion of the other; but this does not lead to a conflict. The religious difference does not generate a conflict ... The cultural diversity generates conflict. When I stop doing what I'm doing with you and I start praying somewhere else, excluding the others in the world. He is strong in other religions; he is much less strong in the Catholic religion, because I have never seen a Catholic say: "I will not go to school tomorrow morning because I must confess ... I have to go to Mass ... etc". (Father, President of parents' association, Italian, Catholic)

As we have seen before, conflicts from adults are mainly between individuals, but some collective identities are mentioned (Muslim identity or majority faith identity): conflicts arise especially when it is possible to identify visible aspects and religious symbols of the others (veil, traditional clothes, hat, etc.). A dilemma appears when extreme attitudes are shown: someone decides to make "a crusade" for the maintenance of the traditional/majority religion and its symbols; someone else tries to remove all the symbols that distinguish the national religious identity (FG-4-MI-ad). In both cases, religious neutrality seems impossible to reach, as a neutral attitude seems unreal, because religious differences need space to express themselves.

In general, for adults, cultural diversity generates more conflicts than religious diversity (FG-5-MI-ad): undoubtedly, a religious practice can affect relationships, having social/relational implications, namely excluding someone who does not share the same religious practices and create links with similar believers. However, when the religious belief is extreme and radical, it causes violent rejection of people with other religious background, and then it becomes a source of conflict. Religions lived as totalizing and closed ideologies create a social and cultural divide: in this perspective, more religion corresponds to less social integration.

When a religious belief becomes extreme, then it is a source of conflict. (Mother, Switzerland/African origin, Protestant)

More religion, less integration, because religion prevails over the main goal of creating a human community with shared human values. If religion presents a partial point of view, then there is the clash of civilizations, closure, religions become theocracies, become a modus vivendi 
and operandi, an obstacle for the formation of a true human and educational community. (Male, School leader)

Where there is extremism and radicalism there is no integration. (Male, IRC Teacher)

It's true. If religion is lived as a religion with all the symbols, with a brand, as a way of thinking, there is no dialogue. (Mother, Switzerland/African origin, Protestant, FG5-MI-ad)

In FG2-BS and 3-BG-ad, adults confirm a cultural explanation of school conflicts, which depend on the attitude of each student or teacher or parent. Often, the ethnic diversity in intergroup interactions led to the explosion of the conflict; later, religious diversity intervenes to increase the conflictual climate. Religion is an instrument (and not the cause) for school conflict, but the ideological manipulation and exploitation of religion make the conflict worse. Adults repeat that conflicts are generated mainly by group dynamics of sympathy or antipathy, majority-minority interactions, family habits, ethnic factors, etc. At the end of this list, teachers put the religious topic as a conflict generator in adult dynamics.

It is not the religion that creates barriers; in my opinion, religion is often exploited. This year, I have witnessed some quarrels that were not religious based. Students sometimes tell me: "My classmates have offended my God or have insulted him", but it was a quarrel born for other reasons, and only after that the religious factor intervensses. (Female, Italian Teacher)

The ethnic factor certainly intervenes in the conflict first; often, the religious factor intervenes only later, to make it even harsher. The students give that explanation, but the theme is not that. (Mother, Italian, Catholic)

If students ask not to be close to each other, the reasons are very different, it is not for religious reasons; it is more for sympathy or antipathy. (Male, Italian Teacher)

Perhaps, it is more for ethnicity than for religion. (Female, School leader)

Perhaps, this happens more among adults than among adolescents. (Male, Italian Teacher, FG3-BG-ad) 
Finally, we give evidence to some considerations emerging in the discussion of FG6-MI-ad and FG1-BS-ad: non-religious causes are considered by the FG participants as the most important explanation of school conflicts. Conflicts are generated by competition for scarce resources, non-acceptance and recognition of the others, incommunicability and intolerance. This interpretation confirms that religion is only a pretext, a spark that makes the conflict explode. Religion diversity represents the most visible aspect of the conflict, but the triggering causes are based on the socio-economic divide between rich and poor people.

From the point of view of adults, the conflict is mainly a material and power conflict; teachers also recall the idea of a political and cultural colonization, based on the use of religions to justify oppression and abuses. The majorityminority contraposition, the native-immigrant divide, the gender gap, all the disparities can be explained in terms of unequal distributions of economic, social and power resources among the population, from the views of adult participants to FGs. Therefore, religion is seen as a cultural instrument to exacerbate the conflict in contexts marked by inequality and disparity.

Religion is only the tool of insult and abuse. Religious difference could be a pretext. We have seen an ideological conflict that has developed in a verbal crescendo that becomes increasingly heavy. The cause is the nonacceptance of the other and his/her difference. Religious affiliation makes everything explode. It is a pretext, but the cause is another. (Male, School leader, FG6-MI-adults)

During History and Geography classes, especially during the last year of lower secondary schools, when we face exploitation problems and conflictual perspectives, it is important to look for historical causes and to help students understand how religion has been exploited for political ends. It is also important to reconstruct the history of the Christian religion and other religions, to analyze the attempts of abuses and to carry forward the discourse of imperialism. (Female, Teacher, Italian, Catholic, FG 1- BS-adults)

Open Conclusions: Overcoming the Generational Cleavage, Recognizing Material and Identity Claims

Although students and adults agree with the opinion that religious identity is not very important in the school environment (Chapter 22), religious diversity is normally experienced, expressed, taken for granted, orhidden in multicultural 
TABLE 23.7 Religious divide among generations

\section{Students' narratives}

Protagonists of conflict

Peer conflicts

Verbal and physical violence

Teasing, superficiality, derision

Variety of bad words, offense, curses, provocation

Expression of feeling and emotions

Religious-based bullying

Group-centrism

Focus on degree of religious freedom from parents

Reference to prejudice, racism, extremism

Strategy of ignoring conflict and hiding religious diversity

Rare intervention and mediation of conflicts by adults

Religious issue, important identity component

Cultural, religious and identity divide

Religion as independent dimension to express personal and collective identity

\section{Adults' narratives}

Spectators in front of conflicts

Peer, teacher-student, teacher-parent conflicts

Verbal violence

Dispute, controversies

Quarrel, verbal disagreement

Complaint and playing the victim

Words as weapons

Closure, insider/outsider distinction

Focus on the control of men on women through religion

Reference to integration

Representation of conflict under adults' control

Silence or dedicated lessons as main strategies

Religious issue as unimportant question at school

Socio-economic and gender divide

Religion as an instrument to exacerbate

the conflict in contexts marked by inequality and disparity

SOURCE: AUTHOR'S PERSONAL ELABORATION

schools, and affects the educational process. Religion seems to become an educational and public matter, especially when conflicts appear. In this conclusion, it is interesting to synthesize briefly the different point of view of students and adults, in the description, analysis and interpretation of the religious-based conflict in classrooms. We try to summarize this analysis proposal in the following table. 
First, the FGs' analysis highlights that the role of students is mainly that of protagonists of their narratives. They tell concrete and detailed stories, quite adherent to reality, offering a description of differentiated kind of conflicts in which they are directly involved. Moreover, students identify more cases of religious-based conflict than adults do. Adults give a simplified version of conflicts, referring to single episodes, to experiences told by colleagues or students, and to isolated and non-generalizable cases: they are mainly spectators in these events, while observing something considered to be not very dangerous or important.

The students' list of school conflicts includes a broader and a more differentiated series of conflicting experiences, above all referring to experiences between peers (intra and interreligious). They report detailed stories, highlighting verbal and physical violence, a religious-based violence motivated by religious belonging and belief of victim and/or perpetrators, violence that is almost absent from the stories of adults, who mostly talk about the use of "words as weapons". Conflicts are interpreted by students as a result of superficial attitudes and habits to make fun of classmates with a different religious background, using a large variety of provocative expression, curses, and blasphemies. The victims, often, refer to negative feelings and emotions, experienced during the conflict, shown a total and direct involvement.

Adults refer mainly to conflicts among students, but consider also teacherstudent, teacher-parents' conflicts. They highlight, above of all, examples of verbal violence and lack of respect for their role. They describe a lot of disputes, controversies, quarrel and verbal disagreement, for example between Catholic teachers and Muslim students, female teachers and Muslim fathers, etc. In the conflictual situation, moreover, adults discuss cases of complaints and (false) accusation made by students, which are often "playing the victim": for adults, in fact, students cannot always be considered as victims of religious bullying or excluded or discriminated basing on their religious belonging. Perhaps, students use this issue looking for justification and excuses for their negative or problematic behaviors.

The conflictual situations are interpreted by students as group dynamics and attitudes that looks at the religion of others from the perspective (and the superiority) of their religion of belonging, while adults point out the closure of the majority (Catholic) group, making a clear distinction between insiders-outsiders.

It must be added that the main issue of the arguments, from the students' point of view, concerns freedom (and autonomy) in religious choice from their parents (as confirmed by the Word Frequency Query (see §5.1)), while for the adult participants in the FGS, mainly women, teachers belonging to the 
national and religious majority, the object of the dispute often concerns women's role in school and society. In the Word Frequency Query, moreover, students make several references to negative phenomena that affect interethnic and interreligious conflicts at school (such as prejudices, racism, extremism, radicalism, etc.); at the same time, teachers among adults refer mainly to the positive goal of integration in multi-cultural schools, which is a word that does not appear in any students' discussion.

Last but not least, to young people, religion represents an important cultural dimension per se, since it deeply affects the construction of students' identity. The religious component of the personal, social, and cultural identity is fundamental since it is connected to the story of the immigrant families and to the collective experience of transmission and socialization of culture and values from one generation to another. Instead, adults think that the religious issue is not so important and relevant, especially in the school environment.

Young people tend to distance themselves from an excessive and painful involvement in conflicts, using the strategy of ignoring religious attacks or fighting when they are stronger than classmates, but the main strategy is to stay (im)mobile and resist, waiting for the conflict to end, in a scene where adults are not very present or active. On the other hand, adults tend to minimize school conflicts, conflicts that are always represented under the control of teachers, adults, and educational institutions, with the illusion of playing an important educational role in preventing conflictual situations.

Finally, a sort of generational divide emerges from the different ways to read and interpret religious-based conflicts at school. For adults, the socio-economic issue (inequalities) relating to immigration (and to women's condition) provides the main reason: religion is a pretext for the conflict, as well as the most visible and manifest aspect, legitimized and culturally accepted, to justify the division between groups. Religion is the fuse that bursts the conflict, transforming an already incandescent situation marked by disparities and scarce resources. In fact, these adults grew in a political era in which the main reference was the class or gender conflict and, for that reason, it is quite normal for them to refer mainly to the material socio-economic nature of the conflicts.

For students, instead, the question of identity and belonging to the group is the most important, in a contemporary era in which conflict is interpreted mainly by cultural, ethnic and religious categories (Santagati et al., 2017): they emphasize the cultural nature of conflicts, thus suggesting not only the ethnicization, but also the culturalization and religiouzation of politics. The religious dimension is the bullet that deeply hurts identity dimensions linked to personal, family, communitarian elements. 
On the one hand, adults underestimate the question of the religious identity, considering it as a controversial and public issue; on the other, students underestimate the socio-economic issue, which will probably become more important in the transition to adulthood. Although they give different interpretation to the conflicts, adults and students use a similar strategy: they refuse to address topics that are considered to be very contradictory and problematic, i.e. religious and spiritual questions in a material and consumerist era (Kristeva, 2016), work socialization and career opportunities in the jobless society (Lodigiani, Santagati, 2016), etc. Overcoming this generational divide in the interpretation of conflict, and nurturing the possibility of a good life together in schools and inside the society, means that religion is an important element perse for individuals and groups, an independent aim and sphere of life. At the same time, it is important to deconstruct the role played by religion, as a dependent dimension and an instrument affected by other dimensions of social life (such as politics, economics, etc.).

Our study, therefore, re-draws the attention to the challenge of working on disparities, not forgetting cultural identities and preserving religious identity, without the fear of being excluded in terms of relationships and educational pathways when this identity is expressed. The challenge -clearly underlined by Zanfrini (2019)- consists in facing socioeconomic inequalities, accepting and recognizing religious identities, promoting cultural exchange and contaminations among peers - a combination of different dimensions that has long been characterizing the Italian vision of educational/social integration in multi-cultural environments (Colombo, Santagati, 2017). Once again, it is time to better combine the cognitive learning with the relational inclusion, by experimenting in schools (and not only there) a space for a "normal experience" of expression of religious minority identities; by promoting the freedom to (not) continue with the familiar tradition in terms of religious belonging, without any imposition or violence, but rather with the family's guidance and support. Other efforts have to be done, in terms of research, in order to recognize the overlap of the disparity deriving from religious belonging with other social, economic and cultural divides, analyzing the intersection of these disadvantage factors and tracing routes to combine equal opportunity in education with guarantee of rights and solidarity (Zanfrini, 2019). It is time to inhabit, accept, and manage the conflict within the democratic frame of the interculturalism (Santagati, Zanzottera, 2018) basing on the idea of dealing with controversies (Cavalli, 2016), transmitting the capability to listen, discuss and face the controversial issues that divide public opinion, and find in democracy a way to make decisions in this controversial world. 